\title{
Disentangling natural and anthropogenic drivers of changes in a shallow lake using palaeolimnology and historical archives
}

\author{
Grzegorz A. Kowalewski • Ryszard Kornijów • Suzanne McGowan • \\ Anna Kaczorowska - Krystyna Bałaga - Tadeusz Namiotko • \\ Michał Gąsiorowski · Agnieszka Wasiłowska
}

Received: 11 February 2015/Revised: 21 September 2015/Accepted: 21 September 2015/Published online: 28 September 2015 (C) The Author(s) 2015. This article is published with open access at Springerlink.com

\begin{abstract}
Shallow lakes are susceptible to catastrophic regime shifts characterised by the presence or absence or macrophytes. However, the long-term controls on macrophyte succession in shallow lakes are incompletely understood. To investigate this, we analysed multiple sediment proxies in Lake Rotcze (Eastern Poland), a small, shallow and densely macrophyte-covered lake to (1) reconstruct the 'reference conditions' (sensu WFD) and development of the lake in recent centuries, (2) compare historical evidence with the sedimentary record, and (3) identify the natural and anthropogenic drivers of macrophyte succession. Before the twentieth century, conditions
\end{abstract}

Handling editor: Katya E. Kovalenko

\section{G. A. Kowalewski ( $\square)$}

Department of Biogeography and Palaeoecology, Adam Mickiewicz University, Dzięgielowa 27, 61-680 Poznan, Poland

e-mail: ichtys@amu.edu.pl

R. Kornijów

Department of Fisheries Oceanography and Marine Ecology, National Marine Fisheries Research Institute in Gdynia, Kołłąaja 1, 81-332 Gdynia, Poland

\section{S. McGowan}

School of Geography, University of Nottingham,

Nottingham NG7 2RD, UK

\section{A. Kaczorowska}

Department of Hydrobiology, University of Life Sciences in Lublin, Dobrzańskiego 37, 20-262 Lublin, Poland in the lake may be referred to as 'reference conditions'. Subsequently forest clearance in the catchment resulted in lower water transparency, but concurrent catchment drainage lowered water levels and increased macrophyte development. Since 1950 elevated nutrient supply and climatically driven increases in water levels led to the deterioration of water transparency and partial macrophyte withdrawal. At the end of the twentieth century lake-level drawdown led to low phytoplankton biomass and clear water creating a novel ecosystem where macrophytes invade the whole lake. These patterns suggest that both natural and anthropogenically induced water level fluctuations have been critical drivers of macrophyte development.

\section{K. Bałaga}

Department of Physical Geography and Palaeogeography, Maria Curie-Skłodowska University, al. Kraśnicka 2 cd, 20-718 Lublin, Poland

T. Namiotko

Laboratory of Limnozoology, University of Gdańsk, Wita Stwosza 59, 80-308 Gdańsk, Poland

M. Gąsiorowski

Institute of Geological Sciences, Polish Academy of

Sciences, Twarda 51/55, 00-818 Warsaw, Poland

A. Wasiłowska

Faculty of Geology, Warsaw University, Żwirki i Wigury 93, 02-089 Warsaw, Poland 
Keywords Aquatic macrophyte succession -

Lake-level changes · Multi-proxy analysis · Water Framework Directive · Novel ecosystem . Charophytes

\section{Introduction}

Macrophytes play a crucial role in shallow lake ecosystems (Scheffer, 2004) and are essential to assess the ecological quality of lakes and their 'reference condition' as defined by the European Union Habitats Directive and European Union Water Framework Directive (WFD). The presence and diversity of macrophytes are important in lake ecosystem evaluation for nature conservation (Salgado et al., 2010) and macrophyte-dominated, clear-water lakes are often the target of lake restoration measures (Moss, 1998; Hilt et al., 2006; Ogdahl \& Steinman, 2014). Substantial changes to the dynamics and composition of submerged plant communities have occurred over the last 200 years in many shallow Northern European lakes including sites from the UK (Davidson et al., 2005, Ayres et al., 2008, Sayer et al., 2010a; Salgado et al., 2010; Bennion et al., 2011a, b), Denmark (McGowan et al., 2005) and Poland (Kowalewski et al., 2013). However, the driving forces of macrophyte succession in shallow lakes have not been clearly identified (Scheffer, 2004).

Most long-term macrophyte studies have focused on macrophyte community degradation or species extirpations in shallow lakes as a result of anthropogenic processes (mainly eutrophication), rather than appearance of macrophytes (Davidson et al. 2005; Jeppesen et al., 2000, 2009; Salgado et al., 2010). This knowledge gap results largely from the lack of longterm observation data (Davidson et al., 2013), which are also essential to an understanding of the trajectory of macrophyte community shifts (Egertson et al., 2004; Gregory-Eaves \& Beisner, 2011; Madgwick et al., 2011; Davidson et al., 2013). Long-term (decadal-centennial scale) changes are scarcely perceptible in botanical observations because documentary evidence is scant and usually covers short-time periods (e.g. Davidson et al., 2005). Long-term observation of both natural- and human-influenced conditions are required to determine the drivers of plant succession which often act concurrently (e.g.
Jeppesen et al., 2014) and so place complex pressures on the lake ecosystem. Palaeolimnology is a wellestablished method to approach these questions (Battarbee, 1999; Davidson et al., 2013) because the limitations of the methods are now well understood (e.g. Davidson et al., 2013; Birks, 2014) and multiproxy analyses can be used to reconstruct past macrophyte and biotic communities. Particularly effective are comparative studies of palaeo-records and historical archives (e.g. Tibby, 2003; Davidson et al., 2005; Salgado et al., 2010; McGowan et al., 2012).

Lake Rotcze, our case study, is covered with macrophytes over the entire lake bottom, with elodeids dominating in the central part of the lake and charophytes closer to the lake shore (Lorens \& Sugier, 2010). The lake and catchment have experienced many historical transformations, although they started relatively recently, at the turn of the 19th-20th century (Kowalewski, 2012, 2013). Typical of many lakes in this region, Lake Rotcze catchment has been extensively drained over the last 100 years. However, in comparison to other lakes in the area, hydrological alterations to the lake are less substantial because it is located at the end of a lake-mire complex (Kowalewski, 2012). According to historical archives and published datasets, Lake Rotcze had previously only sparse macrophyte cover but lost its "pre-disturbance" condition relatively recently (Kowalewski, 2013) when changes in the catchment resulted in the establishment of macrophytes in the lake. Therefore, tracking macrophyte succession in this lake offers a unique opportunity to study the influence of both natural and anthropogenic activity starting from an undisturbed condition, which can be considered to represent 'reference conditions' as required by the WFD (Bennion \& Battarbee, 2007; Bjerring et al., 2008).

The general aim of this study was to verify whether the current macrophyte-dominated regime of Lake Rotcze is a natural/pristine condition or a newly established phenomenon, as suggested by historical plant records or whether the macrophytes have been present in the lake in the recent past. We aimed to determine whether and how past lake-level and other changes have influenced the macrophyte cover. We also sought to reconstruct pre-disturbance community structure to establish 'reference conditions' of the lake. Our particular goals were to (1) reconstruct 
changes in the catchment and lake with an emphasis on macrophyte cover using quantitative multi-proxy palaeolimnological analysis (plant and animal macrofossils, pollen and green algae, diatoms, ostracods, chlorophyll and carotenoid pigments, Cladocera, Chironomidae and geochemistry from lead-210 dated sediment cores), (2) compare sedimentary records with historical records of catchment changes and botanical records, and (3) assess how natural factors and human forcing, related mostly to catchment changes, controlled macrophyte development and associated changes in the food web.

\section{Materials and methods}

Study site

Lake Rotcze $\left(51^{\circ} 22^{\prime} \mathrm{N}, 23^{\circ} 06^{\prime} \mathrm{E}\right)$ is located in a lakemire complex in the Uściwierskie Lowering in the southern part of Polesie (Kowalewski, 2012). The lake area is 42.7 ha, with a mean depth $1.9 \mathrm{~m}$ and maximum depth $4.3 \mathrm{~m}$ (Wilgat et al., 1991). The lake is polymictic (Kornijów \& Halkiewicz, 2006) with a small surface catchment (101-120 ha) (Kowalewski, 2013), and a larger underground watershed of 749 ha with domination of calcareous rocks (Dawidek et al., 2013). Surface catchment land use is dominated by arable land (38\%), pastures and meadows (48\%) (Smal et al., 2005). Land cover changes in the lake catchment have consisted mostly of forest cutting (poor oak-hornbeam forest) and agricultural activity as well as drainage of the surrounding mires (Kowalewski, 2013). Drainage activity has more than halved the catchment area of the lake and at present almost $30 \%$ of the lake catchment is covered by the lake (Suchożebrska \& Chabudziński, 2007). Lake sediments are over $10 \mathrm{~m}$ thick in the central part of the lake (Okruszko et al., 1971), but are absent in the shallow eastern and southern parts of the lake bottom due to wind activity, which counteracts sedimentation.

Botanical surveys of the lake were first conducted between 1955 and 1957 by Fijałkowski (1959) who described mainly emergent taxa in the shore zone (Phragmites australis (Cav.) Trin. ex Steud., Typha angustifolia L., Eleocharis palustris (L.) Roem. \& Schult., and Schoenoplectus lacustris (L.) Palla). The N and NW shore were overgrown by sedges dominated by Carex diandra Schrank and Carex lasiocarpa Ehrh. and floating-leaved species Nymphaea candida J.Presl \& C. Presl and Potamogeton natans $\mathrm{L}$. forming a belt close to the shore. Submerged macrophytes from a community dominated by Myriophyllum sp. and floating-leaves plant were present only in the southern part. Examination made by Popiołek (1988) in the years 1979-1984 revealed a similar flora but patches of some new species such as Myriophyllum spicatum $\mathrm{L}$. were found in the SE part of the lake and, sporadically Najas marina L. (s. 1.) and Stratiotes aloides L. Detailed investigation in 2000-2001 and 2005 showed the presence of 17 submerged species with elodeids dominating (nearly $50 \%$ average cover) in the central, deeper part of the lake, including Elodea canadensis Michx., Stratiotes aloides, Ceratophyllum demersum L., Myriophyllum spicatum and many Potamogeton: P. lucens L., P. pectinatus L., P. crispus L., P. rutilus Wolfg. and, infrequently, P. compressus L. (Lorens \& Sugier, 2010). The sub-dominant group was charophytes ( $40 \%$ average cover, mainly in the shallower part of the lake), including Chara globularis Thuill., Ch. hispida L. Chara vulgaris L., Ch. intermedia A.Braun and Ch. contraria A.Braun ex Kütz. appeared sporadically. Floating-leaved species were less numerous and represented by $N$. candida, Nuphar lutea (L.) Sibth. \& Sm. and Potamogeton natans. The depth range of submerged plants was from 0.4 to $4 \mathrm{~m}$, whereas floating-leaved plants grew from 0.8 to $1.5 \mathrm{~m}$. The dominant Elodea canadensis formed monoculture patches in the deepest part of the lake, but in shallower depths it grew alongside Ceratophyllum. Floating-leaved species rarely grew with charophytes. The \%PVI index (\% plant volume infested) in 2000 was $34.5 \%$ (Lorens \& Sugier, 2010). PVI is calculated as the area of macrophyte coverage multiplied by the plant height divided by the water depth (Canfield et al., 1984).

Field and laboratory work

Three fresh sediment cores were sampled at a distance between cores of approximately $1 \mathrm{~m}$ from an anchored raft in 2005 at the depth of $250 \mathrm{~cm}\left(51^{\circ} 22^{\prime} 40^{\prime \prime} \mathrm{N}\right.$, $23^{\circ} 06^{\prime} 50^{\prime \prime} \mathrm{E}$ ) using a gravity corer (UWITEC Ltd., Austria) equipped with a 59-mm inner diameter tube. In order to overcome the problem of clogging the tube opening by densely growing vegetation, the end of the tube was supplied with the metal oblique cutting edge, resembling a needle (Kornijów \& Kairesalo, 2013). Immediately after sampling, all cores were sectioned 
into $1 \mathrm{~cm}$ layers by means of a sediment slicer (Kornijów, 2013) and stored at $4^{\circ} \mathrm{C}$ until further analysis. The first core (70 cm long) was divided in the laboratory into sub-samples for ${ }^{210} \mathrm{~Pb}$ dating, and analyses of chemistry, pigments, pollen, diatoms, Cladocera, and Chironomidae. The remaining two cores (50 cm long) were used for macrofossils and ostracods.

Dating

Methods for ${ }^{210} \mathrm{~Pb}$-dating and constructing the chronology are described in Gąsiorowski (2008) and provide reliable dates for approximately the last 100 years. Some chronological markers, which allow us to assess the approximate time of changes, were drawn from cartographic and historical sources (Kowalewski, 2013).

\section{Biological proxies}

\section{Pollen analysis}

Sub-samples for pollen analysis were taken every $10 \mathrm{~cm}$ down the sediment core and prepared using the Erdtman's acetolysis method (Faegri \& Iversen, 1975) including a preliminary $\mathrm{HCl}$ and $\mathrm{HF}$ treatment to remove carbonate and silica, followed by hot $\mathrm{KOH}$ digestion. Two Lycopodium pellets were added to each $1 \mathrm{~cm}^{3}$ sample to estimate pollen concentration (Stockmarr, 1971). Sporomorphs were stained with acid fuchsin and mounted in pure glycerine. A minimum of 550 terrestrial pollen grains were analysed, except for two samples $(10,20 \mathrm{~cm}$ depth), where the pollen concentration was very low (total counts of 400 and 175 pollen grains, respectively). The upper $10 \mathrm{~cm}$ of core was not analysed for pollen because microfossil concentrations in the unconsolidated sediments were exceptionally low. Pollen from terrestrial plants was collated into four groups (trees, herbs, ruderals, and cultivated plants). The pollen percentages were based on the sum of trees and shrubs (AP-arboreal pollen) and herbs (NAP_non arboreal pollen) except aquatic and wetland plants.

\section{Macrofossils analysis}

Samples were prepared using standard methods for macrofossil analysis (Birks, 2001) at $1 \mathrm{~cm}$ resolution in the uppermost $20 \mathrm{~cm}$ of the cores and at $5 \mathrm{~cm}$ intervals thereafter. Sediments were washed through $0.125 \mathrm{~mm}$ mesh sieves and the residue sorted under a stereoscopic microscope at 10-100× magnifications. Selected macrofossils were transferred into a mixture of distilled water, glycerine, and ethyl alcohol with addition of thymol for preservation. Macrofossils were identified by comparison with reference material gathered in the Department of Biogeography and Paleoecology UAM in Poznań and in consultation with Tobolski (2000) and Mauquoy \& Van Geel (2007). Results are presented as concentrations per sample volume (about $25 \mathrm{~cm}^{3}$ ).

\section{Diatom analysis}

Diatoms were analysed at a resolution of $3-5 \mathrm{~cm}$. Freeze-dried and weighed samples were prepared using $\mathrm{HCl}$ and $\mathrm{H}_{2} \mathrm{O}_{2}$ digestions of the organic and carbonate sediment matrix (Battarbee et al., 2001) with a quantitative microsphere spike to enable calculation of valve concentrations. At least 400 valves mounted in

${ }^{\circledR} \mathrm{Naphrax}$ resin were counted at magnification $\times 1,000$ and identified with reference to Krammer \& LangeBertalot (1986-1991) and Spaulding et al. (2010).

\section{Cladoceran analysis}

Cladocerans were analysed throughout the core at 1-cm intervals in the top $20 \mathrm{~cm}$ and at 5-cm intervals thereafter. Cladoceran remains were prepared according to Frey (1986) where $1 \mathrm{~cm}^{3}$ of wet sediment was treated with $10 \% \mathrm{HCl}$ to eliminate carbonates, followed by $10 \% \mathrm{KOH}$ to deflocculate the material. The residue was washed with distilled water and sieved using a $33 \mu \mathrm{m}$ sieve. A measured volume of the final residue was stained with safranine and quantitatively sub-sampled for mounting on microscope slides. The enumerated body parts included shells, headshields, postabdomens, postabdominal claws, and ephippia. The most abundant body part was chosen for each species to represent the number of individuals and the percentages were calculated from the sum of individuals. The habitat preferences for cladocerans were based on Bjerring et al. (2009).

\section{Chironomid analysis}

Chironomids were analysed throughout the core at $1-\mathrm{cm}$ intervals in the top $20 \mathrm{~cm}$ and at $5-\mathrm{cm}$ intervals 
thereafter. Preparation procedures of Hofmann (1986) were followed with deflocculation in hot $10 \% \mathrm{KOH}$, acid treatment, sieving with a $180 \mu \mathrm{m}$ screen, and dehydration in $99 \%$ ethanol. Chironomid head capsules were sorted from the sieve residue in a Bogorov counting chamber (Gannon, 1971) under a stereo microscope (magnification 25x) using fine forceps, for a minimum of 50 head capsules (Heiri \& Lotter, 2001; Quinlan \& Smol, 2001), and mounted onto slides in Euparal. In order to obtain a clearer picture of environmental changes taking place in the lake, midges were divided into three ecological groups: epiphytic, benthic, and eurytopic according to their habitat preferences. Taxonomic identifications (to the lowest possible taxonomic level) and habitat preferences were based on Wiederholm (1983) and Brooks et al. (2007). Tanytarsini were distinguished as a separate group due to the difficulties in identification of their remains, and consequently in determination of their ecological group.

\section{Ostracod analysis}

Ostracods were analysed throughout the core at $1-\mathrm{cm}$ intervals in the top $20 \mathrm{~cm}$ and at 5-cm intervals thereafter. Following standard methods (Griffiths \& Holmes, 2000), fresh sediment samples of $1 \mathrm{~cm}$ thickness were washed with tap water, sieved through a $125 \mu \mathrm{m}$ mesh, dried to a constant weight, and then ostracods valves were hand-picked, counted and identified under a stereo microscope at up to $400 \times$ magnification. Species identifications were aided largely by Sywula (1974), Griffiths \& Holmes (2000) and Meisch (2000), with the taxonomy and systematic nomenclature following the latter monograph (Meisch, 2000). Ostracod abundance was expressed as a total number of valves per $10 \mathrm{~g}$ of dry sediment and as percentage relative species/taxa abundances.

\section{Pigment analyses}

Sedimentary chlorophyll (Chl) and carotenoid pigments were estimated in samples at $1 \mathrm{~cm}$ intervals in the upper $20 \mathrm{~cm}$ and below at every $5 \mathrm{~cm}$ down the core sequence. The pigments from $1 \mathrm{~cm}^{3}$ sediment samples were extracted in acetone by ultrasonification (2 min at $10 \mathrm{~W}$, Omni-Ruptor 250). Chlorophyll derivatives (CD) and total carotenoids (TC) were measured spectrophotometrically according to Sanger \& Gorham (1972) in pigment units (PU). Pigments were separated by reversed-phase high performance liquid chromatography (HPLC) on a Dionex liquid chromatograph equipped with a UV-VIS photo-diode array detector using a Waters Spherisorb $\mathrm{C}_{18}$ ODS2 column. The method by Lami et al. (1994) was used to separate pigments which were identified by comparison of retention times and absorption spectra with standards (DHI LAB products). The system was calibrated using external pigment standards (DHI LAB Products).

\section{Sediment chemistry}

Chemical analyses of lake sediments were performed at $1 \mathrm{~cm}$ resolution in the uppermost $20 \mathrm{~cm}$ of the cores and at $5 \mathrm{~cm}$ intervals thereafter. The percentage organic matter (OM) was calculated from loss on ignition (LOI) at $450^{\circ} \mathrm{C}$. Concentrations of carbonates from $\mathrm{Ca}$ and biogenic silica (BSi) were determined according to Krause et al. (1983). Iron compounds, as normative hydroxides, were estimated from total $\mathrm{Fe}$. The residue was assumed to be silicate minerals. $\mathrm{Ca}$, $\mathrm{Fe}, \mathrm{Mg}$, and $\mathrm{Mn}$ metals were determined by atomic absorption spectrometry (AAS) analysis in aqua regia and acid extracts. Phosphorus (P) was analysed from the same extract by the molybdenum blue method. Carbon (C) and nitrogen $(\mathrm{N})$ content of sedimentary organic material was analysed using gas chromatography (CHN Carlo Erba analyzer) on hydrochloric acid-treated samples. The concentration of humic compounds was measured by quantitatively extracting sediments in $0.1 \mathrm{~N} \mathrm{NaOH}$ solution and measuring the absorbance at $270 \mathrm{~nm}$ maximum (Zwoliński \& Górniak, 1999). Concentrations expressed as spectrophotometric pigment unit per gram of dry matter (PU) (where one unit is equivalent to an absorbance of 1.0 in a $10-\mathrm{cm}$ cell dissolved in $100 \mathrm{ml}$ of the solvent).

\section{Zonation}

Each proxy dataset was numerically zoned using the program ZONE (Lotter \& Juggins, 1991) using the recommendations of Bennett (1996). Numerical zonation was carried out by optimal sum of squares partition, and the number of statistically significant splits was determined with the broken-stick model. Data were transformed prior to the zonation in an 
attempt to stabilize the variances (local pollen, pigments, cladocerans, diatoms chironomids, macrofossils) or to express the variables in comparable units (geochemistry). Only species with more than two occurrences and minimum $1 \%$ frequency in any sample were subject to the analysis. Geochemical data were standardized to zero mean and unit variance. Percentage data (diatoms and cladocerans) were square-root transformed and concentration values of all biological proxies transformed by $\log _{\mathrm{e}}(\mathrm{y}+1)$. Diagrams were constructed using Tilia software (Grimm, 1987) included in the Tilia-Graph package (Grimm, 1992).

\section{Results}

Pollen

Zonation identified two statistically significant pollen zones (POZ). POZ -1 (70-45 cm) was characterised by low proportions of NAP (ca. 10\%) and dominated by Alnus, Quercus, Carpinus, and Corylus (Fig. 1) but the latter two genera declined towards the top of the zone. Aquatic plants were represented by Phragmites, Nymphaea alba and Potamogetom s. Eupotamogeton pollen; spores of Sphagnum and Bryales and cenobia of Pediastrum were present. There were high proportions of NAP in POZ -2 $(44-10 \mathrm{~cm})$ with increasing contributions of Poaceae, Artemisia, Rumex sp. and anthropogenic indicator pollen (Cerealia, Plantago lanceolata L.) also increased. Carpinus and (in central part of zone) Alnus pollen decreased. Aquatic plant indicators included Phragmites, N. alba L., N. candida, Potamogeton s. Eupotamogeton, and Sparganium sp. pollen. Proportions of Bryales spores and Pediastrum cenobium gradually increased.

Macrofossils

Two statistically significant local macrofossil assemblage zones (MAZ) were distinguished (Fig. 2). Before 1988 (MAZ-1; 50-8 cm), the Bryales and naiad remains ( $N$. marina and $N$. minor All.) were present in low concentrations throughout the record, with higher abundances in 1940s. Nymphaea and Typha seeds were scarce in this zone. Numerous fossils of birch and pine indicated their presence around the lake edge. A few Cristatella mucedo Cuvier statoblasts in the upper part of the core confirm the development of macrophyte assemblage. After 1988 AD (MAZ-2; 7-1 cm), concentrations of Bryophytes and naiad subfossils declined markedly in favour of Characeae. Remains of trees disappeared almost completely.

\section{Diatoms}

Diatoms were absent in the core below $40 \mathrm{~cm}$ depth, and so data are reported from the upper levels only

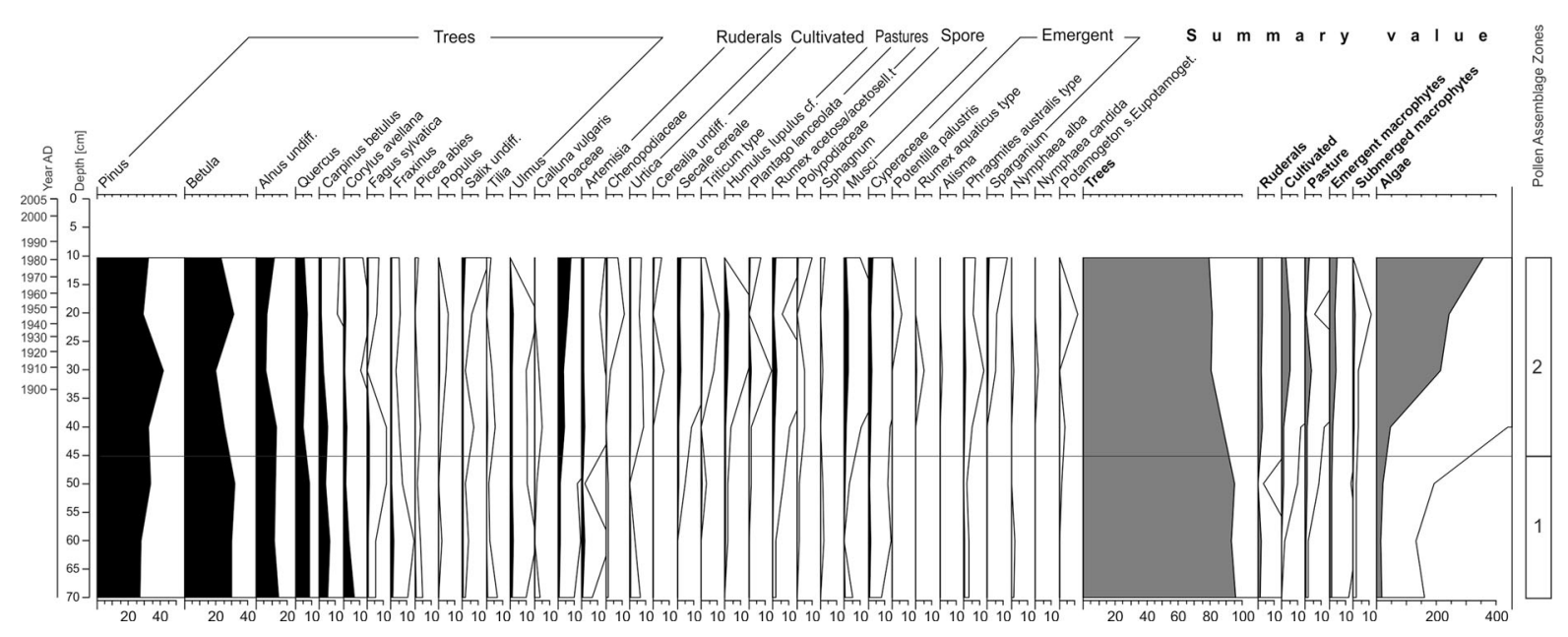

Fig. 1 Relative abundance of pollen, spores, and algae in the sediment core. The pollen percentages were based on the sum of trees and shrubs (AP arboreal pollen) and herbs (NAP non arboreal pollen-except aquatic and wetland plants) 
Fig. 2 Concentrations of macrofossils remains in the sediment core (numbers per $\sim 25 \mathrm{~cm}^{3}$ ). Zone differentiation based on the program ZONE (Lotter \& Juggins, 1991) using the recommendations of Bennett (1996)

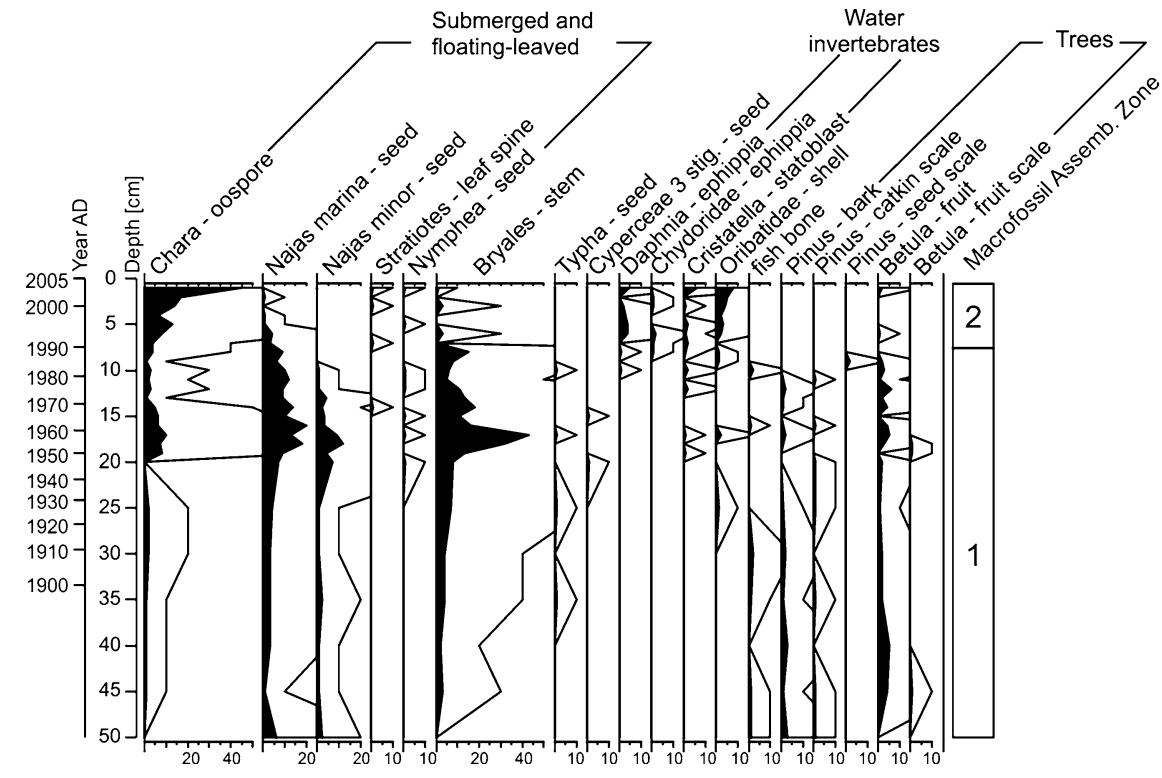

(Fig. 3). Absence of diatoms may be caused by dissolution, but generally low concentrations of the diatom pigments fucoxanthin and diadinoxanthin suggests that diatom production was also low during this period. Sixty one taxa were identified and four statistically significant local diatom assemblage zones (DZ) were distinguished. Cyclotella radiosa (Grunow) Lemmermann, Navicula spp. and Navicula radiosa
Kützing, were present at greatest relative abundance diatom zone 1 (DZ-1) $(<1900, \sim 40 \mathrm{~cm})$ and Achnanthidium minutissimum (Kützing) Czarnecki, Staurosira construens Ehrenberg, Staurosira construens var. binodis (Ehrenberg) P.B.Hamilton and Staurosira construens var. venter (Ehrenberg) P.B.Hamilton were common. In DZ-2 (1915-1965; 32-15 cm) the three Staurosira taxa increased in relative abundance to

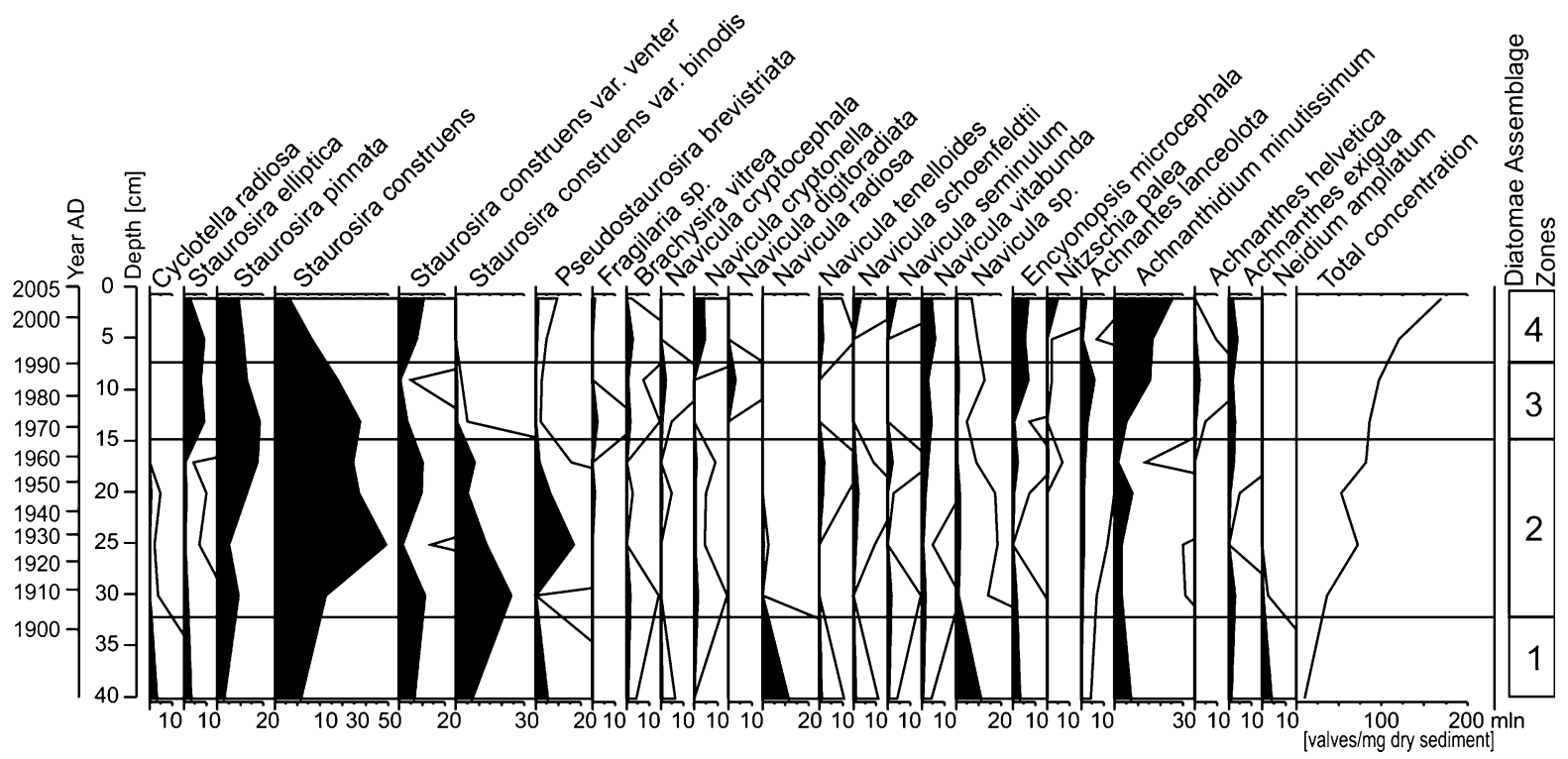

Fig. 3 Relative abundance of selected diatom taxa in the sediment core. Zone differentiation based on the program ZONE (Lotter \& Juggins, 1991) using the recommendations of Bennett (1996) 
become dominant in the assemblage and Pseudostaurosira brevistriata (Grunow) D.M.Williams \& Round also increased, whilst A. minutissimum maintained similar relative abundances to the previous zone and C. radiosa and Navicula radiosa declined to undetectable levels. Between 1965 and 1990 (DZ-3; $15-7 \mathrm{~cm})$ Staurosira construens remained dominant, but was declining along with $P$. brevistriata whereas Staurosira construens var. binodis disappeared, Staurosira elliptica (Schumann) D.M.Williams \& Round appeared for the first time and A. minutissimum and Encyonopsis microcephala (Grunow) Krammer increased. In DZ-4 (after 1990; upper $7 \mathrm{~cm}$ ) $A$. minutissimum increased to become dominant, $S$. elliptica and Staurosira pinnata Ehrenberg remained common and several Navicula species increased in relative abundance.

\section{Chironomids}

Thirty three taxa were found and two statistically significant assemblage zones were identified along the sediment profile (Fig. 4). Concentration of the remains ( 200 HC (head capsules)/10 g dry sediment) and taxa richness was low in zone CHZ-1 $(70-55 \mathrm{~cm})$ and benthic assemblage was dominated by Corynocera ambigua Zetterstedt, reaching $60 \%$ of total chironomid density. Species resistant to oxygen deficit were absent. At the start of zone CHZ-2 $(50-0 \mathrm{~cm})$, Corynocera density abruptly declined along with the entire benthic assemblage but was variable throughout the rest of CHZ-2. Total midge concentrations gradually increased by 2- and 4-fold throughout CHZ-2. Taxonomic richness also increased gradually, at first in all ecological assemblages, and then mainly in the epiphytic group. In the upper $9 \mathrm{~cm}$ of the core there was a reduction in the number of taxa, most significantly in the benthic group. Temporary increases in the percentage of the two consistently present taxa occurred at 16-10 cm (eurytopic Procladius) and 35-20 cm (epiphytic Psectrocladius). The benthic species Chironomus plumosus L. which is tolerant of low oxygen concentrations appeared in the upper $20 \mathrm{~cm}$ core section.

\section{Cladocera}

Thirty four cladoceran taxa belonging to four families were identified and counted. Benthic taxa were dominant and two statistically significant cladoceran zones (CLZ) were distinguished (Fig. 5). Benthic taxa comprised $\sim 80 \%$ the total sum of remains in zone CLZ-1 (70-33 cm) where eurybiontic Alona affinis Leydig, Chydorus sphaericus Mueller and Alona guttata Sars were the most common with smaller proportions of taxa associated with sandy (Chydorus piger $\mathrm{G}$. O. Sars, Monospilus dispar Sars) and muddy (Leydigia spp., Pleuroxus spp.) sediments. Bosmina coregoni Baird was the most common pelagic taxon. Zone 2 (CLZ-2; $32-1 \mathrm{~cm}$ ) was also dominated by benthic taxa, but pelagic taxa percentages increased to $\sim 40 \%$ and Bosmina longirostris Schödler was the most abundant. Increases in plant-associated species, mainly Acroperus harpae Baird, Eurycercus lamellatus Müller and

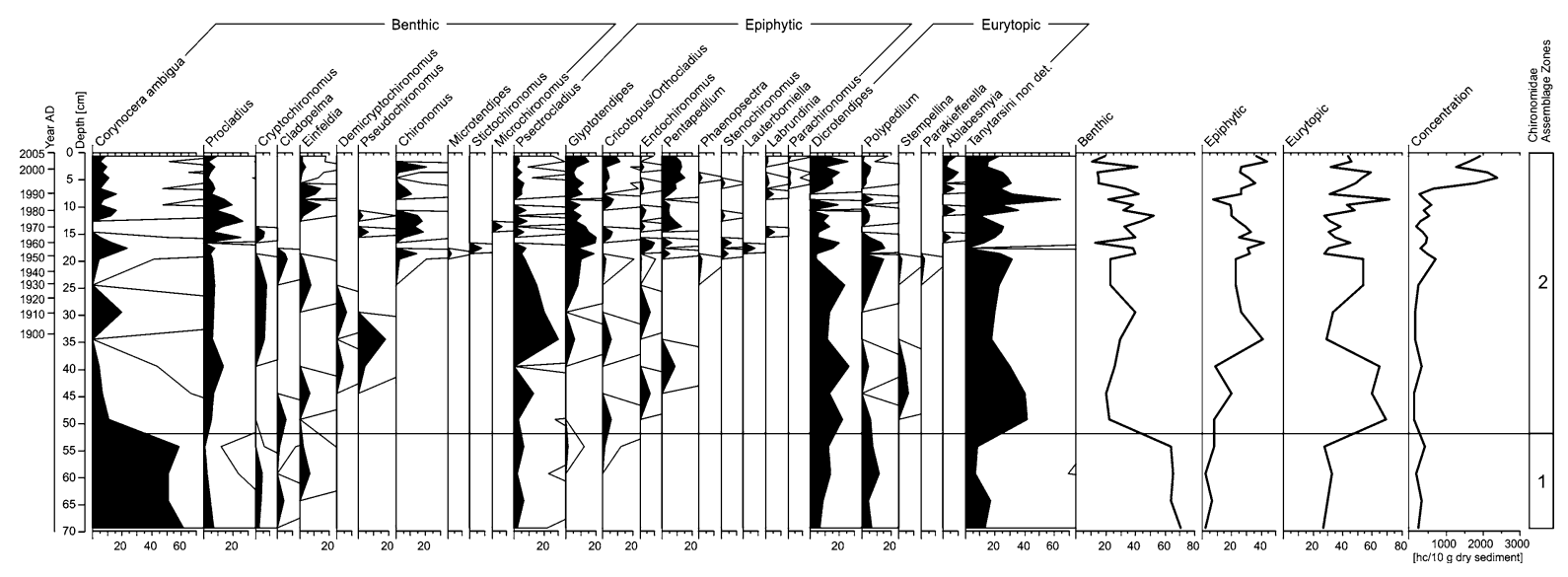

Fig. 4 Relative abundance of Chironomidae head capsules in the sediment core. Zone differentiation based on the program ZONE (Lotter \& Juggins, 1991) using the recommendations of Bennett (1996) 


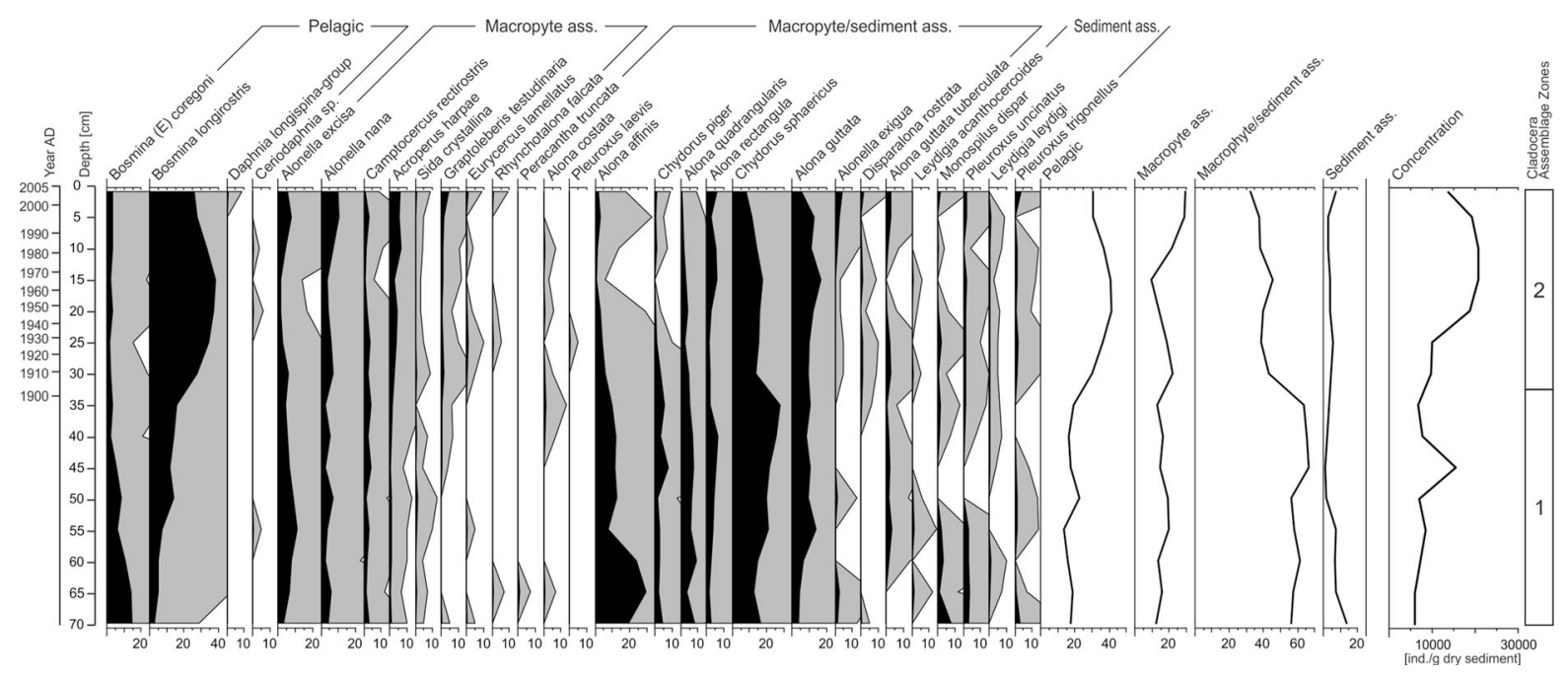

Fig. 5 Relative abundance of cladoceran remains in the sediment core. Zone differentiation based on the program ZONE (Lotter \& Juggins, 1991) using the recommendations of Bennett (1996)

Graptoleberis testudinaria Fischer, and to a lesser extent, Alona costata G. O. Sars were recorded. In the uppermost samples, larger taxa (e.g. Daphnia spp., E. lamellatus) were more abundant.

\section{Ostracods}

The presence of both adult and juvenile valves as well as complete carapaces (with both valves still attached) of the most dominant species suggests that the ostracod palaeoassemblages were predominantly autochthonous, i.e. preserved in situ thanatocoenoses sensu Boomer et al. (2003), and as such may well reflect environmental conditions in which the ostracods lived. Overall, 13 ostracod species were recovered, and Cypridopsis vidua O. F. Müller (41\%) and Metacypris cordata G. S. Brady \& Robertson (18\%) were dominant. In some samples valves were fragmentary and/or immature (especially the Candonidae family), making identification difficult and, therefore, valves were grouped at genus (or close genera) level. Three statistically significant ostracod zones (OSZ) were identified (Fig. 6). OSZ-1 $(50-33 \mathrm{~cm})$ had low total abundances with co-dominant nektobenthic $M$. cordata and $C$. vidua, accompanied by true inbenthic candonids. These assemblages disappeared in OSZ-2 (32-15 cm), which was almost completely deprived of ostracod remains except for a few valves of the genus Candona. In OSZ-3 $(14-1 \mathrm{~cm})$ the total abundance generally increased between the base (c. 50 valves per $10 \mathrm{~g}$ of dry sediment; Candona, Pseudocandona and Cypria ophtalmica Jurini/Physocypria kraepelini G. W. Muller) and the core top (1000 valves per $10 \mathrm{~g}$ of dry sediment; dominated by $C$. vidua and M. cordata).

Pigments

Two statistically significant pigment zones were distinguished in the core (Fig. 7). The lower part of core $(70-9 \mathrm{~cm})$ had relatively low concentrations of chlorophyll derivates (CD) and pigment composition indicated cyanobacteria and/or chlorophytes (luteinzeaxanthin) and cryptophytes (alloxanthin). The presence of chlorophyll $b$ and lutein indicate either chlorophytes or aquatic macrophytes. Above $35 \mathrm{~cm}$ a slight increase in the concentration of all pigments (chlorophylls and carotenoids) was observed. Fucoxanthin and diadinoxanthin (diatom marker) appeared in some samples reflecting the presence of diatoms/ siliceous algae. At $23 \mathrm{~cm}$ depth lutein and alloxanthin maxima indicate abundant chlorophytes and cryptophytes, and at $20 \mathrm{~cm}$ depth transient increase in zeaxanthin relative to lutein suggests greater contribution of cyanobacteria in algal assemblages. Between 8 and $1 \mathrm{~cm}$ diadinoxanthin, chlorophyll $a$, and chlorophyll $c 2$ rapidly increased, lutein and neoxanthin concentrations and $\mathrm{CD} / \mathrm{TC}$ ratios were high. 
Fig. 6 Relative abundance of ostracods shells in the sediment core. Zone differentiation based on the program ZONE (Lotter \& Juggins, 1991) using the recommendations of Bennett (1996)
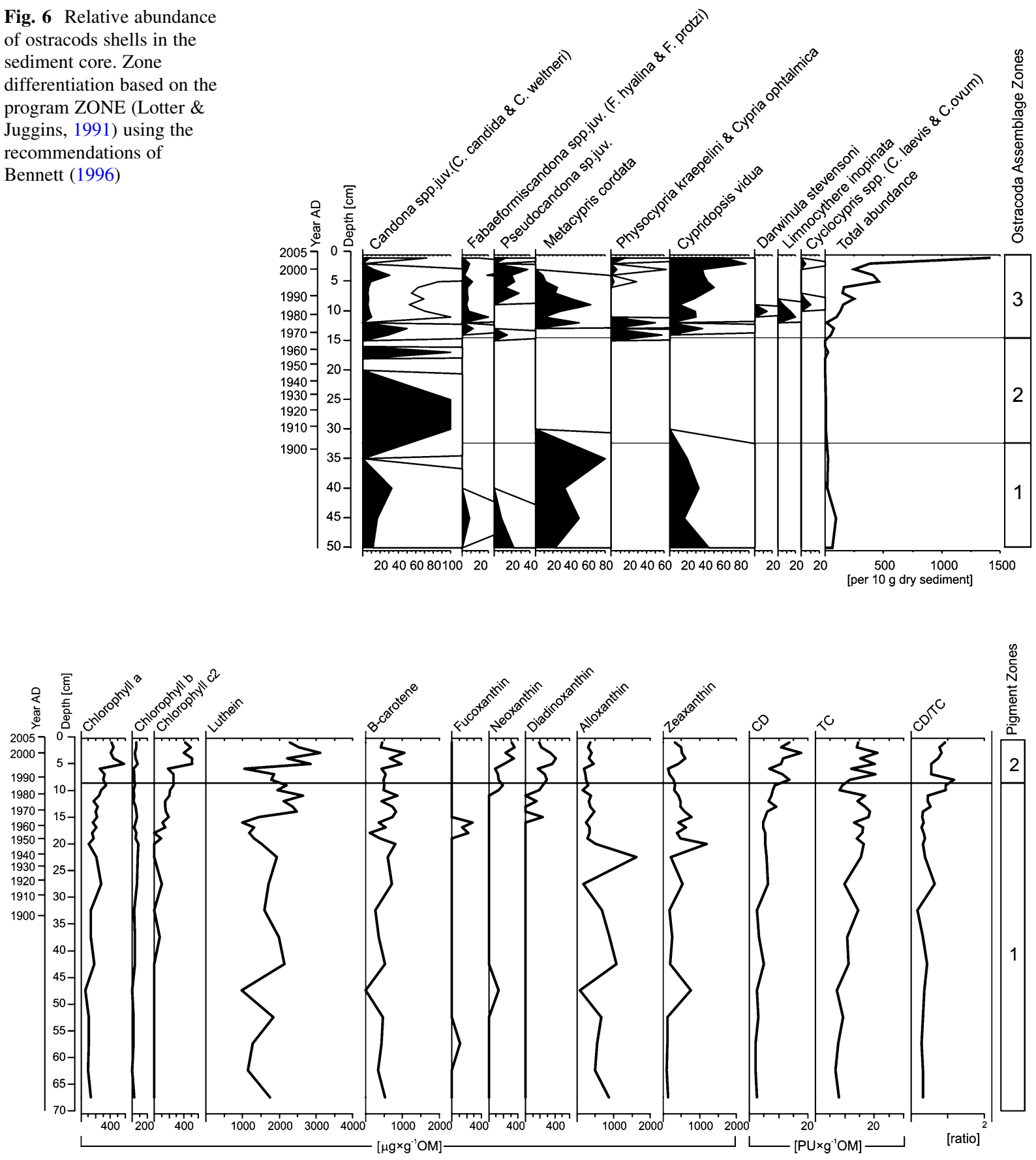

Fig. 7 Pigment stratigraphy in the sediment core. $C D$ chlorophyll derivatives, $T C$ total carotenoids. Zone differentiation based on the program ZONE (Lotter \& Juggins, 1991) using the recommendations of Bennett (1996)

\section{Geochemistry}

Four statistically significant zone were distinguished (Fig. 8) with this first zone I $(70-33 \mathrm{~cm})$ represented by gyttja deposits where carbonates $>$ organic matter $>$ silicates (with a temporary carbonate decline at the $45 \mathrm{~cm}$ level). In Zone II $(33-15 \mathrm{~cm})$ carbonate content gradually declined and total organic carbon 
Fig. 8 Chemical analyses of the sediment core. $O M$ organic matter, $\mathrm{BSiO}_{2}$ biogenic silica, $H$ humic substances, $P$ phosphorus, $C / N$ carbon/nitrogen ratio. Zone differentiation based on the program ZONE (Lotter \& Juggins, 1991) using the recommendations of Bennett (1996)

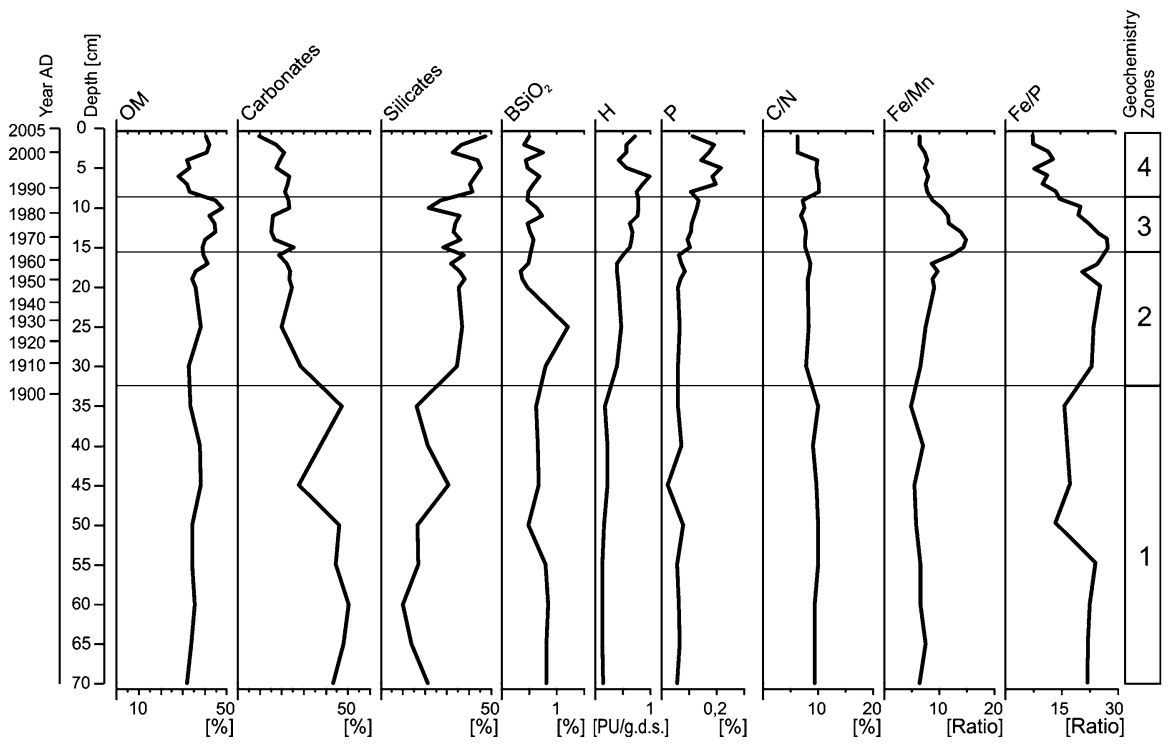

content decreased whereas sedimentation rate increased. In zone III $(9-15 \mathrm{~cm})$ there were high concentrations of organic matter and humic compounds, stable phosphorus concentrations until $15 \mathrm{~cm}$ depth when it increased slightly, and high $\mathrm{Fe} / \mathrm{Mn}$ ratio. In zone IV $(8-1 \mathrm{~cm})$ organic matter declined and silicate concentration increased so silicates $>$ organic matter $>$ carbonate. $\mathrm{C} / \mathrm{N}$ ratios exceeded 10 in this zone.

\section{Discussion}

Pre-disturbance period (pre-twentieth century)

In the period represented by the deepest sediments, the lake catchment was free from human influence (Fig. 9), as evidenced by low densities of anthropogenic indicator pollen and cartographical sources (Kowalewski, 2013). The investigated lake is located in the temperate, deciduous forest zone, thus the scarcity of herbaceous plants in relation to trees (NAP/ AP) suggests very low human pressures even at the regional scale. The low $\mathrm{Fe} / \mathrm{Mn}$ index, and lack of hypoxia-tolerant chironomid species suggests good oxygenation of the near-bottom zone. Low pigment and chlorophyte concentrations document low or at most moderate production in the lake. Although rushes and nymphaeids were present in the littoral zone, the macrophyte cover in the lake was extremely sparse (at least around the coring site), as suggested by the low contribution of cladocerans and chironomids that inhabit macrophytes. In both of these groups, sediment-dwelling species were numerous, such as the chironomid C. ambigua and cladocerans $M$. dispar and Pleuroxus uncinatus Baird. The prevalence of medium-bodied (B. coregoni) over small planktonic cladocera ( $B$. longirostris), with large-bodied Alona affinis and small-bodied $A$. rectangular Sars and $A$. guttata, suggest that there was substantial pressure from predatory fish on planktivorous fish (Johansson et al., 2005) and so high water transparency. A similar pattern is observed in the lake today (Kornijów et al., 2002; Adamczyk \& Kornijów, 2011). Such stable conditions in the absence of evidence for human activity in the lake catchment suggest this period can be designated as 'reference conditions' for the lake (sensu WFD) with the scarce macrophyte cover being due to low lake productivity and high water levels.

Initial changes in lake biota were observed around $55-50 \mathrm{~cm}$ sediment depth (probably first half of the nineteenth century acc. to Gąsiorowski, 2008) when there was a marked decrease in the numbers of benthic cladocerans and chironomids, a feature noted in other lakes in this region (Halkiewicz, 2008). One possible cause could be the development of submerged macrophytes as documented by the pollen and macrofossils (Chara, N. marina, and $N$. minor remains). The presence of phytophilous and photophobic $M$. cordata and $C$. vidua ostracods also 


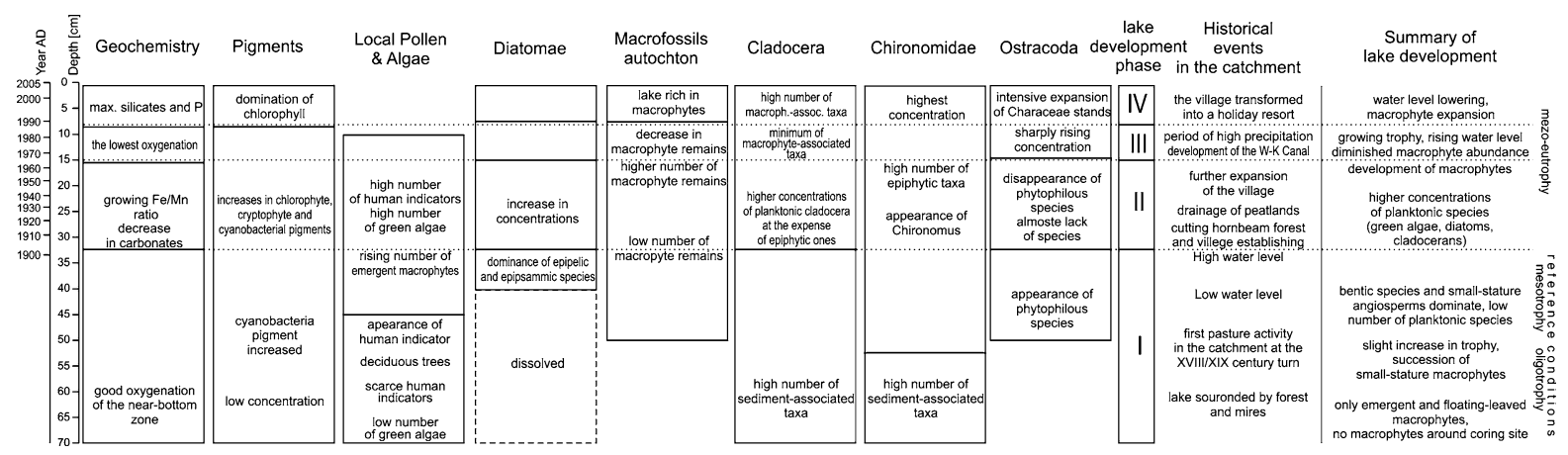

Fig. 9 Summary chart, indicating the main aquatic ecosystem changes in Lake Rotcze. The zone limits of proxies are based on the program zone and associated broken-stick model. W-K Canal Wieprz-Krzna Canal

indicates more submerged vegetation because they live in shallow-water with dense macrophyte cover on organic-rich lacustrine sediments. However, M. cordata appears to favour root-masses and stems of thick rushes or nymphaeids, whereas $C$. vidua develops particularly rich populations within dense stands of Characeae (Roca et al., 1993; Danielopol et al., 1996). Such environmental requirements of the two species reflect conditions of a shallow meso-eutrophic lake with macrophytes.

An increase in the frequency of pollen from cereals, Rumex acetosalacetosella and P. lanceolata at $50 \mathrm{~cm}$ sediment depth indicate the first human impacts in the catchment suggesting both agricultural and pastoral activity close to the lake ( $c f$. Goslar et al., 1999). The map by von Heldensfeld confirms extensive forest clearing at the southern lake shore from at least the turn of the eighteenth and nineteenth century, by the inhabitants of the village of Garbatówka, located south of the lake (Kowalewski, 2013). This pollen chronomarker suggests a date of $\sim 1800$ AD before $50 \mathrm{~cm}$. Subsequently, macrophyte pollen (Phragmites, Potamogeton s. Eupotamogeton), green algae and zeaxanthin pigment (from cyanobacteria) each increased suggesting that the lake became more productive, which may be explained by the initiation of livestock farming. The increased productivity may have enhanced macrophyte development, but another possible cause could be a decline in water level because precipitation in the region decreased during the second half of the nineteenth century (Mięsiak et al., 2005), as confirmed by a decrease in carbonates at $45 \mathrm{~cm}$, probably resulting from lowered ground water charge.

Despite evidence for eutrophication, the sediment composition remained quite stable and the lake was still close to 'reference (sensu WFD) conditions' at the time corresponding to $40 \mathrm{~cm}$ depth. Dominance of epipelic and epipsammic diatoms, such as Achnanthes, Fragilaria, and Navicula (Kawecka \& Eloranta, 1994), as well as the presence of only one planktonic species $(C$. radiosa) suggest that water transparency was high and so benthic production dominated the lake with macrophytes providing habitat for the periphyton. Well-developed benthic algal communities can reduce total phosphorus availability for phytoplankton through uptake and maintain high redox potential to prevent sedimentary phosphorus release to the water (Liboriussen \& Jeppesen, 2003). The low Fe/Mn (Naeher et al., 2013) and high Fe/P ratios support this interpretation because $\mathrm{Fe} / \mathrm{P}$ ratios $>15-20$ usually prevent phosphorus release (Jensen et al., 1992). Therefore, it appears that these feedbacks maintained high water transparency despite increased trophic status (Scheffer \& Nes, 2007). The presence of $C$. radiosa and $N$. radiosa in DAZ-1 but not DAZ-2, suggests lower nutrient conditions and lower, intermediate alkalinity in the earlier zone relative to the subsequent period (Bennion \& Simpson, 2011). Due to the short history of human impact in the catchment the lake started to deviate from 'reference conditions' in the $19^{\text {th }}$ century, which is relatively late compared to other parts of Europe (e.g. Bjerring et al., 2008).

Deforestation, settlement, drainage

in the catchment (the first statistically significant horizon boundary)

The first statistically significant change in geochemistry, diatoms, cladocerans, and ostracods occurred at 
the turn of the nineteenth and twentieth century (30-35 cm depth) and coincided with the development of Grabniak village (Kowalewski, 2013). At this time a slight increase in water level is inferred from the higher concentrations of planktonic cladocera and benthic chironomids at the expense of epiphytic ones. The complete disappearance of phytophilous ostracods and sporadic occurrence of Candona (mainly $C$. candida which is not closely associated with aquatic vegetation), may also indicate a decline in macrophytes due to a water level increase. The slight water level rise may have been caused by the wetter climatic conditions at this time which reinstated prior water levels following the dry period (Mięsiak et al., 2005) and indeed water level in Lake Rotcze in 1892 was estimated to be $0.9 \mathrm{~m}$ higher than in modern times (Kowalewski, 2012). Deforestation of the catchment may have also caused the water table in the catchment to rise.

Development of Grabniak village led to considerable changes in land use in the lake catchment. Clearing of the dry-ground forests surrounding the lake is clearly indicated by a decrease in the hornbeam curve and the name Grabniak derives from the Polish name (grab) of Carpinus betulus L. which dominated the trees. The human population count from 1905 records 276 village inhabitants residing in 38 houses (Paniasiuk, 2013). The geodetic plan from 1909 documents the location of part of those houses in the direct vicinity of the lake on its eastern and southern shore (Kowalewski, 2013). During the 1st World War (1914-1918), many people were relocated to Siberia, and some of the fields were left fallow, because the front line was located close to the lake. In spite of this, by 1921 , the number of inhabitants had increased to 320, residing in 53 houses (Panasiuk, 2013). The development of the village resulted in enhanced erosion of the catchment and shore, reflected in the sediment composition, as a significant increase in mineral matter and a decline in the relative proportions of carbonates occurred. The increase in relative abundance of Staurosira construens, Staurosira construens var. venter, Pseudostaurosira brevistriata and Staurosira pinnata which are common in many shallow lakes and inhabit benthic and pelagic habitats may reflect expansion of littoral habitat as water levels increased, which would be well suited to these tychoplanktonic taxa, and they may have outcompeted the planktonic Cyclotella radiosa. The humic content in the sediment also increased twofold, probably due to erosion of forest soils.

The developing settlement caused substantial changes in the lake ecosystem during the early 1900 s, as reflected in sediments from a depth of $20-25 \mathrm{~cm}$. The growing $\mathrm{Fe} / \mathrm{Mn}$ ratio suggests the lower oxygen conditions in the water/sediment interface from increased biological production as recorded by increases in diatom concentrations and pigments (fucoxanthin and diadinoxanthin) and chlorophyte, cryptophyte, and cyanobacterial pigments (lutein, alloxanthin, and zeaxanthin) (Romero-Viana et al. , 2009). Higher production caused an increase in the concentration of planktonic cladocera (primarily $B$. longirostris) and a decrease in epiphytic ones. The total concentration of chironomids also grew, with the first appearance of Chironomus sp., resistant to oxygen deficits.

Human-induced regulation of water levels has a long history in the Polesie Lubelskie Region (eastern Poland) (Wilgat et al., 1991). In Lake Rotcze the water level was artificially lowered in the 1920s by digging melioration ditches to drain the peatlands covering the western part of the lake catchment, and so this probably expanded light penetration to the lake phytobenthos countering the increasingly turbid water conditions. This drainage resulted in succession of willow (Salix) shrubs (Fig. 1), overgrowing the drained peatland. Further development of Grabniak village north of the lake in the 1930s intensified anthropogenic pressure and the instatement of a ditch draining the fields east of the lake (visible in aerial photographs from 1951) accelerated the nutrient inflow (Kowalewski, 2013). The new lake water level slowly stabilised to a lower level similar to the current one. Light conditions in the lake improved, resulting in the development of Potamogeton (inferred from pollen), Najas sp., and Chara sp. (inferred from macrofossils) macrophytes around the 1950s which expanded towards deeper parts of the lake. The number of leafless Bryales stems, originating from the eroded shore confirms that water levels fluctuated. The in situ presence of submerged macrophytes is also suggested by the macrophyte-associated $C$. mucedo statoblasts (cf. Mamakowa, 1989; Väliranta et al., 2005). The first appearances of epiphytic chironomids (Pentapedilum and Lauterborniella) and maximum numbers of Glyptotendipes further strengthen the evidence for well-developed macrophyte stands. In 
contrast, the ostracod record shows no indication of submerged macrophytes development since 1920s, which may be due to taphonomy because the increase of organic matter and humic substances could have encouraged valve dissolution. Dissolution of this type is frequent in eutrophic conditions, as indicated by the presence of Staurosira construens (De Deckker, 2002).

Further lowering of oxygen concentrations in nearbottom water layers and increase in lake trophic status since the half of the twentieth century is documented in the sediment composition (Fe/Mn ratio and phosphorus concentration increased), the species composition of chironomids (increase in hypoxia-resistant taxa such as Chironomus and Procladius, and decline in oligo-mesotrophic taxa such as Cryptochironomus and Cladopelma), and changes in the cladocerans (disappearance of Chydorus piger). The development of macrophytes is also reflected in elevated chlorophyll $a$ concentrations.

Eutrophication (the second statistically significant horizon boundary)

Geochemistry, diatoms, and ostracods changed significantly ca. 1960 (depth of 14-16 cm), most probably because of progressive eutrophication. Vegetation surveys from 1955 to 1957 noted clumps of Nymphaea candida and Potamogeton natans at the southern shore, sparse stands with Myriophyllum sp. and floating-leaves plant in the deeper part of the littoral and numerous patches of rushes in the northwest and western littoral but no Najas sp. or charophytes (Fijałkowski, 1959). Small species such as Najas are easily overlooked in plant surveys and so this may explain the inconsistency with the macrofossil record (Caspers, 2000), but charophytes are rarely missed. Macrophyte-associated cladocera reached a minimum, and were replaced by planktonic cladocera. Concurrently the numbers of epiphytic chironomids decreased. Diatom concentrations and diatom pigments (diadinoxanthin and fucoxanthin) increased the eutrophic diatom $S$. elliptica appeared and maximum $\mathrm{Fe} / \mathrm{Mn}$ values indicated minimal oxygenation of sediments.

Another high precipitation period occurred between 1966 and $1982(14-10 \mathrm{~cm})$, and there was a snow melt flood in 1979 (Michalczyk et al., 2011), but simultaneous catchment modifications to drainage including the major infrastructure development of the Wieprz-Krzna Canal (Wilgat et al., 1991) resulted in only a minor rise in water level. However, such catchment modification changed groundwater discharge, lowering calcium carbonate supply. Therefore, alkaliphilous Staurosira construens and Staurosira pinnata declined in zone DAZ-3 and were replaced more generalist taxa such as A. minutissimum (Bennion \& Simpson, 2011). At the same time, increased precipitation may have enhanced external nutrient loading (Jeppesen et al., 2015), depicted in rising content of humic substances and phosphorus. An asphalt road was constructed along the southern and eastern lake shore and improved accessibility to the lake. This led to intensive development of recreation facilities (Kowalewski, 2013), contributing to an increase in lake trophic status. Monitored lake phosphorus concentrations increased from 5 to $10 \mu \mathrm{g} \mathrm{l}^{-1}$ in summer 1966 (Kowalczyk, 1978) to $50 \mu \mathrm{g} \mathrm{l}^{-1}$ in summer 2000. In spite of the increase in trophic status and slight water level increase, macrophytes persisted on the lake bottom, although they became less numerous. The slow reappearance of the phytophilous ostracods (initially together with the transient occurrence of two other typical littoral species Limnocythere inopinata Baird and Darwinula stevensoni Brady and D. Robertson), may also reflect macrophyte presence. The presence of Potamogeton, in spite of lack of their pollen at a depth of $10 \mathrm{~cm}$, is documented by turions of Potamogeton crispus at a depth of 9-12 cm.

Macrophyte expansion (the third statistically significant horizon boundary)

Between 1987 and 89 (depth of 9-7 cm) there were statistically significant changes in geochemistry, pigments, diatoms, and macrofossils which indicate an expansion of macrophytes, particularly Chara. This development was favoured by the gradual natural lowering of the water level recorded since 1982 (Michalczyk et al., 2011). A rich macrophyte flora was already observed in the 1980s by one of the authors (R. Kornijów, unpublished data), and confirmed by detailed studies in 2000 and 2005 (Lorens \& Sugier, 2010). Such a macrophyte-dominated state is maintained today in spite of frequent water level fluctuations of up to $0.8 \mathrm{~m}$ (Michalczyk et al., 2011). Macrophytes are recorded in the sediments by a 
considerable increase in Chara sp. oospore, the chlorophyll $a$ and $c 2$ concentrations, high concentration of lutein and neoxanthin and an increase in the total concentration of epiphytic chironomids and cladocera. Disappearance of $M$. cordata at the core top (after 2000AD), a synchronous peak in C. vidua relative abundance and elevated total ostracod counts could indicate intensive expansion of Characeae stands and good oxygen conditions at the bottom of the coring site.

In 2006-2007, the dominant phytoplankton species (green algae Closterium dianae Ehrenberg ex Ralfs, $C$. acutum Breb and species from genera Scenedesmus and Pediastrum) indicate a eutrophic lake state, whereas measured chlorophyll $a$ concentrations of $6.7 \mu \mathrm{g}^{-1}$ (Wojciechowska \& Solis, 2009), indicate a rather lower mesotrophic state, possibly result from extensive macrophyte cover. Such low concentrations of chlorophyll $a$ also occurred in 2000 (Kornijów et al., 2002) leading to high water transparency $(2.8 \mathrm{~m}$ secchi depth). The clear-water state was supported by very high (almost 1:1) ratio of predatory/non-predatory fish whereas the zooplankton/phytoplankton biomass ratio was 12.4 (Kornijów et al., 2002). Modern zooplankton sampling confirms that mediumand large-bodied Cladocera species (B. coregoni, Diaphanosoma brachyurum Liévin, Daphnia cucullata G. O Sars, Eudiaptomus graciloides (Lilljeborg) dominated (Adamczuk \& Kornijów, 2011) and in agreement there were many Daphnia ephippia in the sediments since 1990 ( $<6 \mathrm{~cm}$ depth) (cf. Jeppesen et al., 2001). The lake has never experienced the phytoplankton dominated state in its recent history, as in the case in other shallow lakes in the region with minimal human impacts (Kornijów et al., submitted).

Evaluation of palaeolimnological reconstruction methods

Our study confirmed the potential of a palaeolimnological approach for assessing 'reference conditions' (e.g. Leira et al., 2006; Bennion \& Battarbee, 2007; Bjerring et al., 2008; Bennion et al., 2011a, b). Many palaeolimnological studies have used diatoms to infer the amount of nutrients (DI-TP) and changes in taxonomic composition (Leira et al., 2006; Bennion et al., 2011a, b), although there are some problems with applying diatom transfer function for shallow lakes (Bennion et al. 2011a, b). They use inter-site comparisons (Leira et al., 2006; Bjerring et al., 2008) or detailed investigations of a single site (e.g. Davidson et al., 2005). Some use single proxies (e.g. Ayres et al., 2008) but most are multi-proxy (e.g. Bjerring et al., 2008; Davidson et al., 2013). Here, we present a complete multi-proxy sequence of lake changes from pristine conditions which existed here relatively recently comparing with other European lakes. The identified change is primarily characterised by the appearance of macrophytes instead of only changes in macrophyte composition, described by other authors (see Introduction). It resulted not only from anthropogenic pressures but also from natural, climatically induced changes.

Palaeolimnology has the advantage of providing information on long-term succession and past ecological conditions (Schindler, 2009). Variability in macrophyte abundance on inter-annual to sub-decadal timescales can be substantial (Sayer et al., 2010a, b) leading to considerable uncertainty in determination of successional trends. Lakes sediments typically integrate temporal responses (5-6 years in older sediments and 2-3 years in the surface) and thus reduce inter-annual variability (Adrian et al., 2009). In this respect, sedimentary, macrofossils and pollen analyses might be considered more reliable in the reconstruction of long lasting succession. Macrofossil analysis can also cover lake species persisting for many years on vegetative reproduction only (Birks, 2001). The record is continuous, although some bias in reconstruction must be taken into account (Birks, 2014). The reconstruction of lake-level fluctuation in deeper lakes is best archived using a transect of multiple cores recovered from a gently sloping littoral part of the lake (Digerfeld, 1986; Hannon \& Gaillard, 1997). However, in shallow lakes of small size which are typically largely colonised by macrophytes over the entire lake bottom, the examination of the multiproxy data from even one core taken from the lake, when supported by historical data, can provide a reliable reconstruction of past changes (Davidson et al., 2005).

\section{Conclusions for lake management}

Although the present ecological state in Lake Rotcze represents high ecological status (for Polish Lakes and macrophyte index for assessing the ecological status 
of lakes in terms of WFD see Ciecierska \& Kolada 2014), the lake cannot be considered a reference lake, because the lake and catchment have undergone many transformations (the presence of urban areas, including many recreational facilities, also in the direct vicinity of the lake shore; a quickly falling proportion of forest in the catchment; disturbed hydrological conditions in terms of both surface and groundwater). Therefore, if the concept of 'reference conditions' are inappropriate in this novel ecosystem (sensu Hobbs et al., 2006) perhaps other approaches should be considered.

In Rotcze Lake reference condition inferred from palaeolimnology inform us that contemporary conditions are not an equivalent to "pre-disturbance" (reference) condition. A novel (Hobbs et al., 2006), macrophyte-dominated ecosystem was inadvertently created as a result of synergistic human and natural influences. The pristine lake was oligotrophic, devoid of macrophytes, deeper and its catchment was covered totally with forest and wetlands. Therefore, this new state fulfils reference conditions in terms of water quality but not in terms of ecology.

The basic premise of WFD is the assessment of a lake ecological state through a comparison with a reference condition (undisturbed condition). The hidden assumption is that lake ecosystems have a particular state, undisturbed by human activity (quite close to pristine with some possible minor deviations). Because of human pressure this state has changed and the lake should have been recovered to this previous, undisturbed conditions. Such assumption could be theoretically implemented in deep lakes, which are relatively resistant to natural changes, but is more challenging in shallow lakes, where environmental conditions change dynamically due to natural succession, including the onset of macrophytes, and this should be taken into account when assessing 'reference conditions' (cf. Bennion et al., 2011a, b).

Our study confirms that the assessment of 'reference condition', even in a region with late arrival of human pressures, requires investigation of time spans older than c. $1850 \mathrm{AD}$ as the primary baseline date (comp. Leira et al., 2006; Bijerring et al., 2008; Bennion et al., 2011a, b). Our long-term observations confirmed the results of many previous studies that water level changes in lakes may be an important mechanism for macrophyte succession (Jeppesen et al., 2015, Table S3). Importantly, natural or artificial water level drawdown in our study encouraged macrophyte growth whereas water level increases resulted in only minor changes. This mechanism may be important within inter-annual to sub-decadal (Sayer et al., 2010a, b) and decadal-centennial timescales. Moreover, the changes in groundwater discharge resulted in considerable reduction of nutrient supply including calcium ions, which has major impact on lake water quality.

Low growing species, like Characeae, are desirable in lakes used for recreation, but achieving Charadominated lakes is challenging when applying restoration measures (Hilt et al., 2006). In the case of Lake Rotcze this type of vegetation developed spontaneously, probably because of lower water levels, counteracting a potential shift into phytoplankton dominated state, even though the lake was becoming increasingly productive. In the year 2005, Chara stands dominated in the shallow part of the lake and elodeids were dominant only in the deepest part ( $<3 \mathrm{~m}$ ) (Lorens \& Sugier, 2010). Incorporating Lake Rotcze into the drainage network substantially lowered natural fluctuations in water level. This mechanism will also counteract water level increases in the future as climate models predicted enhanced net precipitation in the North temperate zone (IPCC, 2014), particularly during winter (Jeppesen et al., 2014).

Acknowledgements The study was supported by the State Committee for Scientific Research, Project No. P06S00127. We are grateful to Lucyna Namiotko for her help in the ostracod analysis. The comments of two anonymous reviewers helped to substantially improve this manuscript and we appreciate their inputs.

Open Access This article is distributed under the terms of the Creative Commons Attribution 4.0 International License (http:// creativecommons.org/licenses/by/4.0/), which permits unrestricted use, distribution, and reproduction in any medium, provided you give appropriate credit to the original author(s) and the source, provide a link to the Creative Commons license, and indicate if changes were made.

\section{References}

Adamczuk, M. \& R. Kornijów, 2011. Crustacean communities as food resources for fish in shallow Polesie lakes with contrasting development of submerged macrophytes. Oceanological and Hydrobiological Studies 40: 11-18.

Adrian, R., C. M. O'Reilly, H. Zagarese, S. B. Baines, D. O. Hessen, W. Keller, D. M. Livingstone, R. Sommaruga, 
D. Straile, E. Van Donk, G. A. Weyhenmeyer \& M. Winder, 2009. Lakes as sentinels of climate change. Limnology Oceanography 54: 2283-2297.

Ayres, K., C. D. Sayer, M. Perrow \& E. Skeate, 2008. Palaeolimnology as a tool to inform shallow lake management: an example from Upton Great Broad, Norfolk, UK. Biodiversity and Conservation 17: 2153-2168.

Battarbee, R. W., 1999. The importance of palaeolimnology to lake restoration. Hydrobiologia 395(396): 149-159.

Battarbee, R. W., 2000. Palaeolimnological approaches to climate change, with special regard to the biological record. Quaternary Science Review 19: 107-124.

Battarbee, R. W., V. J. Jones, R. J. Flower, N. G. Cameron, H. Bennion, L. Carvalho \& S. Juggins, 2001. Diatoms. In Smol, J. P., H. J. B. Birks \& W. M. Last (eds), Tracking Environmental Change Using Lake Sediments, Vol. 3. Kluwer Academic, Dordrecht: 155-202.

Bennett, K. D., 1996. Determination of the number of zones in a biostratigraphical sequence. New Phytologist 132: 155-170.

Bennion, H. \& R. Battarbee, 2007. The European Union Water Framework Directive: opportunities for palaeolimnology. Journal of Paleolimnology 38: 285-295.

Bennion, H. \& G. L. Simpson, 2011. The use of diatom records to establish reference conditions for UK lakes subject to eutrophication. Journal of Paleolimnology 45: 469-488.

Bennion, H., R. W. Battarbee, C. D. Sayer, G. L. Simpson \& T. A. Davidson, 2011a. Defining reference conditions and restoration targets for lake ecosystems using palaeolimnology: a synthesis. Journal of Paleolimnology 45: 415-431.

Bennion, H., G. L. Simpson, N. J. Anderson, G. Clarke, X. Dong, A. Hobæk, P. Guilizzoni, A. Marchetto, C. D. Sayer, H. Thies \& M. Tolotti, 2011b. Defining ecological and chemical reference conditions and restoration targets for nine European lakes. Journal of Paleolimnology 45: $533-544$.

Birks, H. H., 2001. Plant Macrofossils. In Smol, J. P., H. J. B. Birks \& W. M. Last (eds), Tracking Environmental Change Using Lake Sediments, Vol. 4., Zoological Indicators Kluwer Academic Publications, Dordrecht: 49-74.

Birks, H. J. B., 2014. Challenges in the presentation and analysis of plant-macrofossil stratigraphical data. Vegetation History Archaeobotany 23: 309-330.

Bjerring, R., E. G. Bradshaw, S. L. Amsinck, L. S. Johansson, B. V. Odgaard, A. B. Nielsen \& E. Jeppesen, 2008. Inferring recent changes in the ecological state of 21 Danish candidate reference lakes (EU Water Framework Directive) using palaeolimnology. Journal of Applied Ecology 45: 1566-1575.

Bjerring, R., E. Benares, S. Declerck, E. Gross, L.-A. Jansson, T. Kairesalo, A. Halkiewicz, R. Kornijów, J. M. Conde-Porcuna, M. Seferlis, T. Nõges, B. Moss, S. L. Amsinck, B. Vad Odgaard \& E. Jeppesen, 2009. Subfossil Cladocera in relation to contemporary environmental variables in 54 Pan-European lakes. Freshwater Biology 54: 2401-2417.

Boomer, I., D. J. Horne \& I. J. Slipper, 2003. The use of ostracods in palaeoenvironmental studies, or what can you do with and ostracod shells? Paleontological Society Papers 9: 153-179.
Brooks, S.J., P.G. Langdon, O. Heiri, 2007. The identification and use of Palaearctic Chironomidae larvae in paleoecology. Quaternary Research Association Technical Guide No. 10.

Canfield Jr, D. E., J. V. Shireman, D. E. Colle, W. T. Haller, C. E. Watkins Ii \& M. J. Maceina, 1984. Prediction of chlorophyll a concentrations in Florida lakes: importance of aquatic macrophytes. Canadian Journal of Fisheries and Aquatic Sciences 41: 497-501.

Caspers, R., 2000. A comparison of two sampling techniques in the study of submersed macrophyte richness and abundance. Aquatic Botany 68: 87-92.

Ciecierska, H. \& A. Kolada, 2014. ESMI: a macrophyte index for assessing the ecological status of lake. Environmental Monitoring and Assessment 186: 5501-5517.

Danielopol, D.L., D.J. Horne \& R.N. Wood, 1996. Notes on the ecology of Metacypris cordata (Ostracoda, Timiriaseviinae): why does it not colonise groundwater habitats. In: Keen, M.C. (Ed.), Proc. 2nd European Ostracodologists Meeting. British Micropal. Soc., London: 175-179.

Dawidek, J., B. Ferencz \& W. Sobolewski, 2013. Modelling of hydrogeochemical potential of three lake catchments in Polesie region (Eastern Poland). Hydrological Processes 27(12): 1773-1780.

Davidson, T., C. Sayer, H. Bennion, C. David, N. Rose \& M. Wade, 2005. A 250 year comparison of historical, macrofossil and pollen records of aquatic plants in a shallow lake. Freshwater Biology 50: 1671-1686.

Davidson, T. A., M. A. Reid, C. D. Sayer \& S. Chilcott, 2013. Palaeolimnological records of shallow lake biodiversity change: exploring the merits of single versus multi-proxy approaches. Journal of Paleolimnology 49: 431-446.

De Deckker, P., 2002. Ostracod palaeoecology. Geophysical Monograph 131: 121-134.

Digerfeldt, G., 1986. Studies on Past Lake-Level Fluctuations. In Berglund, B. E. (ed.), Handbook of Holocene Palaeoecology and Palaeohydrology. Wiley, New York: 127-144.

Egertson, C. J., J. A. Kopaska \& J. A. Downing, 2004. A century of change in macrophyte abundance and composition in response to agricultural eutrophication. Hydrobiologia 524: 145-156.

Faegri, K. \& J. Iversen, 1975. Textbook of Pollen Analysis, 3rd ed. Munksgaard, Copenhagen.

Fijałkowski, D., 1959. Flora of lakes situated between Łęczna and Włodawa and of the peat-bogs adjacent to those lakes. Annales UMCS, Sectio B 14(3): 131-206 (in Polish with English abstract).

Frey, D. G., 1986. Cladocera Analysis. In Berglund, B. E. (ed.), Handbook of Holocene Palaeoecology and Palaeohydrology. Wiley, New York.

Gannon, J. E., 1971. Two counting cells for the enumeration of zooplankton microcrustacea. Transactions of the American Microscopical Society 90: 486-490.

Gąsiorowski, M., 2008. Deposition rate of lake sediments under different alternative stable states. Geochronometria 32: 29-35.

Goslar, T., M. Ralska-Jasiewiczowa, B. Geel, B. Łącka, K. Szeroczyńska, L. Chróst \& A. Walanus, 1999. Anthropogenic changes in the sediment composition of Lake Gościąż (central Poland), during last 330 yrs. Journal of Paleolimnology 22: 171-185. 
Gregory-Eaves, I. \& B. E. Beisner, 2011. Palaeolimnological insights for biodiversity science: an emerging field. Freshwater Biology 56: 2653-2661.

Griffths, H. I. \& J. A. Holmes, 2000. Non-marine ostracods and Quaternary palaeoenvironments. Quaternary Research Association Technical Guide 8: 1-188.

Grimm, E. C., 1987. CONISS: a Fortran 77 program for stratigraphically constrained cluster analysis by the method of incremental sum of squares. Computer Geoscience 13: 13-35.

Grimm, E.C., 1992. TILIA/TILIA graph. Version 1.2. Illinois State Museum, Springfield.

Halkiewicz, A., 2008. Corynocera ambigua (Insecta, Diptera) subfossils occurrence in recent sediments of four shallow Polesie lakes. Annales UMCS LXIII, 2 sec. C: 31-36.

Hannon, G. E. \& M. J. Gaillard, 1997. The plant-macrofossil record of past lake-level changes. Journal of Paleolimnoloy 18(1): 15-28.

Heiri, O. \& A. F. Lotter, 2001. Effect of low count sums on quantitative environmental reconstructions: an example using subfossil chironomids. Journal of Paleolimnology 26: 343-350.

Hilt, S., E. M. Gross, M. Hupfer, H. Morscheid, J. Mahlmann, A. Melzer, J. Poltz, S. Sandrock, E. M. Scharf, S. Schneider \& K. van de Weyer, 2006. Restoration of submerged vegetation in shallow eutrophic lakes-a guideline and state of the art in Germany. Limnologica 36: 155-171.

Hobbs, R. J., S. Arico, J. Aronson, J. S. Baron, P. Bridgewater, V. A. Cramer, P. R. Epstein, J. J. Ewel, C. A. Klink, A. E. Lugo, D. Norton, D. Ojima, D. M. Richardson, E. W. Sanderson, F. Valladares, M. Vila, R. Zamora \& M. Zobel, 2006. Novel ecosystems: theoretical and management aspects of the new ecological world order. Global Ecology and Biogeography 15: 1-7.

Hofmann, W., 1986. Chironomid Analysis. In Berglund, B. E. (ed.), Handbook of Holocene Palaeohydrology. Wiley, Chichester: 715-727.

IPCC, 2014. Summary for policymakers. In Field, C. B., V. R. Barros, D. J. Dokken, K. J. Mach, M. D. Mastrandrea, T. E. Bilir, M. Chatterjee, K. L. Ebi, Y. O. Estrada, R. C. Genova, B. Girma, E. S. Kissel, A. N. Levy, S. MacCracken, P. R. Mastrandrea \& L. L. White (eds), Climate Change 2014: Impacts, Adaptation, and Vulnerability. Contribution of Working Group II to the Fifth Assessment Report of the Intergovernmental Panel on Climate Change. Cambridge University Press, Cambridge: 1-32.

Jensen, J. S., P. Kristensen, E. Jeppesen \& A. Skytthe, 1992. Iron:phosphorus ratio in surface sediment as an indicator of phosphorus release from aerobic sediments in shallow lakes. Hydrobiologia 235(236): 731-743.

Jeppesen, E., J. P. Jensen, M. Søndergaard, T. Lauridsen \& F. Landkildehus, 2000. Trophic structure, species richness and biodiversity in Danish lakes: changes along a phosphorus gradient. Freshwater Biology 45: 201-218.

Jeppesen, E., P. Leavitt, L. De Meester \& J. P. Jensen, 2001. Functional ecology and paleolimnology: using cladoceran remains to reconstruct anthropogenic impact. TRENDS in Ecology and Evolution 16: 191-198.

Jeppesen, E., M. Søndergaard, H. S. Jensen \& A.-M. Ventäla, 2009. Lake and Reservoir Management. In Likens, Gene E. (ed.), Encyclopedia of Inland Waters, Vol. 1. Elsevier, Oxford: 295-309.
Jeppesen, E., M. Meerhoff, T. A. Davidson, M. Søndergaard, T. L. Lauridsen, M. Beklioglu, S. Brucet, P. Volta, I. González-Bergonzoni, A. Nielsen \& D. Trolle, 2014. Climate change impacts on lakes: an integrated ecological perspective based on a multi-faceted approach, with special focus on shallow lakes. Journal of Limnology 73: 84-107.

Jeppesen, E., S. Brucet, L. Naselli-Flores, E. Papastergiadou, K. Stefanidis, T. Nõges, P. Nõges, J. L. Attayde, T. Zohary, J. Coppens, T. Bucak, R. F. Menezes, F. R. S. Freitas, M. Kernan, M. Søndergaard \& M. Beklioğlu, 2015. Ecological impacts of global warming and water abstraction on lakes and reservoirs due to changes in water level and related changes in salinity. Hydrobiologia. doi:10.1007/s10750014-2169-x.

Johansson, L. S., S. L. Amsinck, R. Bjerring \& E. Jeppesen, 2005. Mid- to late-Holocene land-use change and lake development at Dallund S $\varnothing$, Denmark: trophic structure inferred from cladoceran subfossils. The Holocene 15: 1143-1151.

Kawecka, B. \& P. V. Eloranta, 1994. Ecology Profile of Freshwater and Land Environments Algae. Wydawnictwo Naukowe PWN, Warszawa (in Polish).

Kornijów, R., 2013. A new sediment slicer for rapid sectioning of the uppermost sediment cores from marine and freshwater habitats. Journal of Paleolimnology 49: 301-304.

Kornijów, R. \& A. Halkiewicz, 2006. Uwarunkowania zaburzeń sekwencji odkładania osadów dennych w płytkich jeziorach poleskich w kontekście ich przydatności do badań paleoekologicznych (in Polish). Studia Limnologica et Telmatologica 1: 83-86.

Kornijów, R. \& T. Kairesalo, 2013. A simple solution enabling quantitative sampling of freshwater and marine sediments covered by dense submerged vegetation. Hydrobiologia 716(1): 1-44.

Kornijów, R., W. Pęczuła, B. Lorens, S. Ligęza, J. Rechulicz \& D. Kowalczyk-Pecka, 2002. Shallow Polesie Lakes from the view point of the alternative stable states theory. Acta Agrophysica 68: 61-72.

Kornijów, R., G. Kowalewski, P. Sugier, A. Kaczorowska, M. Gąsiorowski \& M. Woszczyk (submitted to Hydrobiologia) Towards more precisely defined macrophyte-dominated regime: the recent history of a shallow lake in Eastern Poland.

Kowalczyk, C., 1978. Crustacean fauna of the Łęczna-Włodawa Lake District against the Background of Limnological Factors. Part II. The Lake of the IIIrd Degree of Degradation. Annales UMCS. Sec. C XXXIII: 470-498 (in Polish).

Kowalewski, G., 2012. Over 200 years of drainage practices and lake level drawdown in Uścimowskie Lowering (ŁęcznaWłodawa Lake District). Limnological Review 12(4): 179-190.

Kowalewski, G. A., 2013. Changes in Lake Rotcze catchment over the last 200 years: implications for lake development reconstruction. Limnological Review 13(4): 197-207.

Kowalewski, G. A., R. Kornijów, S. McGowan, M. Woszczyk, M. Suchora, K. Bałaga, A. Kaczorowska, M. Gąsiorowski, K. Szeroczyńska \& A. Wasiłowska, 2013. Persistence of protected, vulnerable macrophyte species in a small, shallow eutrophic lake (eastern Poland) over the past two centuries: Implications for lake management and conservation. Aquatic Botany 106: 1-13. 
Krammer, K. \& H., Lange-Bertalot, 1986-1991. Bacillariophyceae. Teil 1-4. In: Ettl, H., Gerloff, J., Heynig, H., Mollenhauer, D. (eds), Süsswasserflora von Mitteleuropa. Gustav Fisher, Stuttgart.

Krause, G. L., C. L. Schelske \& C. O. Davis, 1983. Comparison of three wet-alkaline methods of digestion of biogenic silica in water. Freshwater Biology 13: 73-81.

Lami, A., F. Niessen, P. Guilizzoni, J. Masaferro \& C. A. Belis, 1994. Paleolimnological studies of the eutrophication of volcanic Lake Albano (Central Italy). Journal of Paleolimnology 10: 181-197.

Leira, M., P. Jordan, D. Taylor, C. Dalton, H. Bennion, N. Rose \& K. Irvine, 2006. Assessing the ecological status of candidate reference lakes in Ireland using palaeolimnology. Journal of Applied Ecology 43: 816-827.

Liboriussen, L. \& E. Jeppesen, 2003. Temporal dynamics in epipelic, pelagic and epiphytic algal production in a clear and a turbid shallow lake. Freshwater Biology 48: 418-431.

Lorens, B. \& P. Sugier, 2010. Changes in the spatial structure of submerged macrophytes in Lake Rotcze (Łęczna-Włodawa Lakeland). Oceanological and Hydrobiological Studies 39(4): 65-73.

Lotter, A. F. \& S. Juggins, 1991. POLPROF, TRAN and ZONE: programs for plotting, editing and zoning pollen and diatom data. INQUA Subcommission for the study of the Holocene, Working Group on Data-Handling Methods, Newsletter 6: 4-6.

Mamakowa, K., 1989. Late Middle Polish Glaciation, Eemian and Early Vistulian vegetation at Imbramowice near Wrocław and the pollen stratigraphy of this part of the Pleistocene in Poland. Acta Palaeobotanica 29(1): 11-176.

Madgwick, G., D. Emson, C. D. Sayer, N. J. Willby, N. Rose, M. J. Jackson \& A. Kelly, 2011. Centennial-scale changes to the aquatic vegetation structure of a shallow eutrophic lake and implications for restoration. Freshwater Biology 56: 2620-2636.

Mauquoy, D. \& B. Van Geel, 2007. Plant Macrofossil Methods and Studies: Mire and Peat Macros. In Elias, S. A. (ed.), Encyclopedia of Quaternary Science. Elsevier Science, Amsterdam: 2315-2336.

McGowan, S., P. R. Leavitt, R. I. Hall, N. J. Anderson, E. Jeppesen \& B. V. Odgaard, 2005. Controls of algal abundance and community composition during ecosystem state change. Ecology. 86: 2200-2211.

McGowan, S., P. Barker, E. Y. Haworth, P. R. Leavitt, S. C. Maberly \& J. Pates, 2012. Humans and climate as drivers of algal community change in Windermere since 1850. Freshwater Biology. 57(2): 260-277.

Meisch, C., 2000. Freshwater Ostracoda of Western and Central Europe. Spektrum Akad, Heidelberg.

Michalczyk, Z., Z. Chmiel \& M. Turczyński, 2011. Lake water stage dynamics in the Łęczna-Włodawa Lake District in 1991-2010. Limnological Review 11: 113-122.

Mięsiak, K., W. Szwajgier \& M. Turczyński, 2005. Environmental transformations in lake Lejno catchment basin. Limnological Review 5: 175-181.

Moss, B., 1998. Shallow lakes. Biomanipulation and eutrophication. Scope Newletter 29: 1-45.

Naeher, S., A. Gilli, R. P. North, Y. Hamann \& C. J. Schubert, 2013. Tracing bottom water oxygenation with sedimentary
$\mathrm{Mn} / \mathrm{Fe}$ ratios in Lake Zurich, Switzerland. Chemical Geology 352: 125-133.

Ogdahl, M. E. \& A. D. Steinman, 2014. Factors influencing macrophyte growth and recovery following shoreline restoration activity. Aquatic Botany 120: 363-370.

Okruszko, H., T. Churski \& J. Karpińska, 1971. Torfowiska i gytiowiska w rejonie jezior krasowych Uściwierz na Pojezierzu Łęczyńsko-Włodawskim. Zeszyty Problemowe Postępów Nauk Rolniczych 107: 121-165. (in Polish).

Panasiuk A., 2013. The History of Grabniak (Dzieje wsi Grabniak). http://historia.urszulina.net

Popiołek, Z., 1988. Zróżnicowanie roślinności wodnej i przybrzeżnej na tle warunków siedliskowych w obrębie kompleksu jezior Lubelskiego Zagłębia Węglowego. UMCS 35: 1-108. (in Polish).

Quinlan, R. \& J. P. Smol, 2001. Setting minimum head capsule abundance and taxa deletion criteria in chironomid-based inference models. Journal of Paleolimnology 26: 327-342.

Roca, J. R., A. Baltanás \& F. Uiblein, 1993. Adaptive response in Cypridopsis vidua (Crustacea, Ostracoda) to food and shelter offered by a macrophyte (Chara fragilis). Hydrobiologia 262: 127-131.

Romero-Viana, L., B. J. Keely, A. Camacho, E. Vicente \& M. R. Miracle, 2009. Photoautotrophic community changes in Lagunillo del Tejo (Spain) in response to lake-level fluctuation: two centuries of sedimentary pigment records. Organic Geochemistry 40: 376-386.

Salgado, J., C. D. Sayer, L. Carvalho, T. A. Davidson \& I. Gunn, 2010. Assessing aquatic macrophyte community change through the integration of palaeolimnological and historical data at Loch Leven, Scotland. Journal of Paleolimnology 43: 191-204.

Sanger, J. E. \& E. Gorham, 1972. Stratigraphy of fossil pigments as a guide to the postglacial history of Kirchner Marsh, Minnesota. Limnology Oceanography 17: 840-854.

Sayer, C. D., A. Burgess, K. Kari, T. A. Davidson, S. Peglar, H. Yang \& N. Rose, 2010a. Long-term dynamics of submerged macrophytes and algae in a small and shallow, eutrophic lake: implications for the stability of macrophyte-dominance. Freshwater Biology 55: 565-583.

Sayer, C. D., T. A. Davidson \& J. I. Jones, 2010b. Seasonal dynamics of macrophytes and phytoplankton in shallow lakes: a eutrophication-driven pathway from plants to plankton. Freshwater Biology 55: 500-513.

Scheffer, M., 2004. Ecology of Shallow Lakes. Kluwer Acadamic Publisher, Dordrecht.

Scheffer, M. \& E. H. van Nes, 2007. Shallow lakes theory revisited: various alternative regimes driven by climate, nutrients, depth and lake size. Hydrobiologia 584: 455-466.

Schindler, D. W., 2009. Lakes as sentinels and integrators for the effects of climate change on watersheds, air sheds, and landscapes. Limnology Oceanography 54: 2349-2358.

Smal, H., R. Kornijów \& S. Ligęza, 2005. The effect of catchment on water quality and eutrophication risk of five shallow lakes (Polesie Region, Eastern Poland). Polish Journal of Ecology 53: 313-327.

Spaulding, S.A., D.J. Lubinski \& M. Potapova, 2010. Diatoms of the United States. http://westerndiatoms.colorado.edu

Stockmarr, J., 1971. Tablets with spores used in absolute pollen analysis. Pollen et Spores 13: 615-621. 
Suchożebrska, M. \& Ł. Chabudziński, 2007. Anthropogenic Transformations of the Hydrographical Network in Lake Catchment Areas of the Uściwierz Lowering (ŁęcznaWłodawa Lake District). Limnological Review 7: 225-231.

Sywula, T., 1974. Małżoraczki-Ostracoda. Fauna słodkowodna Polski. PWN, Warszawa-Poznań.

Tibby, J., 2003. Explaining lake and catchment change using sediment derived and written histories: an Australian perspective. Science of the Total Environment 310: 61-71.

Tobolski, K., 2000. Guide book to identification of peat and lake sediments (in Polish). PWN, Warszawa.

Väliranta, M., S. Kultti, M. Nyman \& K. Sarmaja-Korjonen, 2005. Holocene development of aquatic vegetation in a shallow Lake Njargajarvi, Finnish Lapland with evidence of water level fluctuations and drying. Journal of Paleolimnology 34: 203-215.
Wiederholm, T., 1983. Chironomidae of the Holarctic region: keys and diagnoses. Part 1 Larvae. Entomologica Scandinavica Suppl 19: 1-457.

Wilgat, T., Z. Michalczyk, M. Turczyński \& K. Wojciechowski, 1991. The Łęczna-Włodawa Lakes. Studia Ośrodka Dokumentacji Fizjograficznej XIX: 23-140. (in Polish).

Wojciechowska, W. \& M. Solis, 2009. Evaluation of Ecological States of the Lakes in the Łęczna-Włodawa Lakeland on the Basis of Abundance and Community Structure of Phytoplankton. In Chmielewski, T. \& C. Sławiński (eds), Nature and Landscape Monitoring System in West Polesie Region. University of Lifie Science, Institute of Agrophysics Polish Academy of Sciences, Lublin: 200-206.

Zwoliński, P. \& A. Górniak, 1999. Analizy rozpuszczonego węgla organicznego w wodach naturalnych. Aparatura badawcza i Dydaktyczna 11: 37-45. 